\title{
Translating Sarcasm as Killing the Prophets and Making Fun of Them in Some Quranic Verses Into English
}

\author{
Muhammad Maan Mamdouh \\ University of Mosul, Mosul Iraq \\ Dr. Muhammed Ibrahim Hamood (Corresponding author) \\ University of Mosul, Mosul Iraq \\ E-mail: dr-mihamood@uomosul.edu.iq
}

Received: June 8, 2021

Accepted: July 14, 2021

Published: July 19, 2021

doi:10.5296/ijl.v13i4.18872

URL: https://doi.org/10.5296/ijl.v13i4.18872

\begin{abstract}
The current study concentrates on translating the rhetorical meanings of sarcasm in the Holy Quran and the translated texts in an effort to find a sort of compatibility between the two languages. It focuses on the method of sarcasm in some verses of Holy Quran in an endeavour to understand its intended meaning and clarify the variations involved in its translation into the English language. The study aims to produce some conceptions of sarcasm and take them into consideration in observing the original texts for the purpose of showing whether the translators are able to accurately translate the implicit meanings of sarcasm, based on Newmark's Model (1988), "semantic and communicative translation". Qualitative analysis is suitable for the purpose of the study, as it is suited for exploring people's attitudes, opinions, beliefs, perceptions, interactions and behaviors in numerous settings and where the approach is interpretative and the data are presented subjectively rather than statistically.

The study hypothesizes that translating sarcasm leads to some prospect problems for translators; one of the deductions obtained from this study is the variety of translations depending on the translator's understanding of the meaning of the original text. The major findings that the translators have produced distinct translations depending on their understanding of the verse's meanings. In addition, in most cases, the renderings of the three
\end{abstract}


translators look unsuitable because they did not display the sarcastic function as it is in the source text (ST). Consequently, the three translators broadly, failed to express the intentional ironic meaning as it is in the source text (The Holy Quran), and also could not manage to transfer the sarcastic message implied.

Keywords: Translation, Sarcasm, Quranic verses, Semantic and communicative translation

\section{Introduction}

Sarcasm is defined as one of the substantial rhetorical devices used in literary and religious texts for criticism and to show the reverse of everything belonging to society by mocking. Since sarcasm is an element of social interaction among people, it has gained much ground in Arabic culture. Many of the most famed Arab scholars dealt with sarcasm within their studies about various sciences of the Quran and rhetoric. Al-Jurjani (n.d) in (Asrar Al-Balagha) referred to sarcasm through his submitting of diverse kinds of rhetorical devices with relevance to the sciences of the Quran. He describes sarcasm as two conflicting attributes where one of them is used to diminish the value of the opposite one. Interpreters have not given a one particular definition of sarcasm, but it could be deduced from their explanation of the verses in which sarcasm has been adopted. Thus, interpreters defined it using the opposites of words to scoff and make fun of the addressee; and this is clear in God's words like this verse below:

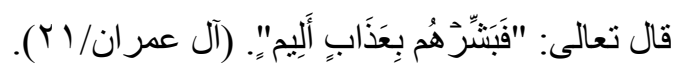

"Then announce to them a painful torment (Al-Hilali and Khan:1977, P.70)". The word (tidings-بشارة) indicates good, but here the word has been used in bad that is, it has been used to give the opposite meaning (Al-Fara`a:1980, P.239).

Al-Masri (1964:13 claims that sarcasm may not be used in a purely linguistic sense; it may be used indirectly depending on the writer's intention. Some scholars think that sarcasm is a kind of metaphor. For instance, Al-Sakkaki (1983:293) proposes that sarcasm belongs to a particular kind of metaphor (sarcastic metaphor), which means exchanging one of the contrary features metaphorically by the other one. According to Al-Zamakhashari (1984:398), he expresses sarcasm indirectly through interpreting some verses of the Quran with reference to its signifying of contrary meaning to its accurate meaning. So, he expressed sarcasm with reversing the meaning when he interpreted this verse:

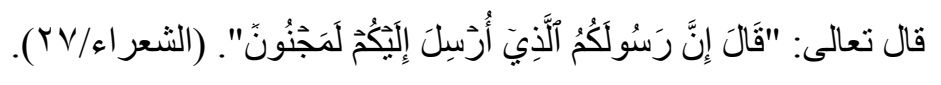

"(Pharaoh) said: Surely your messenger, who is sent to you, is mad. (Muhammad Ali:2002, P.733)". In this verse, Al-Zamakhshari clarified that how could they confess the revelation of the Quran into the Prophet Muhammad (PBUH) and at the same time accuse him of being mad!!! So, reversing the meaning here is for sarcastic purposes. Generally, sarcasm is a rhetorical device used in literary and religious texts to remark that people use it to say the opposite of what is true to criticize something by mocking. "Sarcasm is made of the linguistic process in the form of insinuation that uses harsh words. So, the language of sarcasm comprises words that hurt people". Cudden (1979:338), claimed that sarcasm can be defined 
as saying one thing and meaning another. On the other hand, Haiman (1988:20) who also stated that what is noteworthy to sarcasm is that it is an intended overt irony used by the speaker as a form of verbal aggression. Mc Donald (1999:486), proposes that sarcasm is an indirect form of speech utilized to create a particular impact on the listener as well as linking emotions and thoughts which are less aggressive from what is really on one's mind. A similar idea is made by Toplak and Katz (2000:88), who declare that sarcasm is used to have some influence on listeners which varies from the direct supposition of the speaker in a way that the listeners are informed of the influence intended by the speaker.

\section{Literature Review}

\subsection{Newmark's Theory of Translation}

Peter Newmark (1916-2011), was an English professor on translation at the University of Surrey. He was one of the focal figures in the founding of translation studies. He defines the act of translating as conveying the meaning of a text from one language to another, taking care mainly of the functional relevant meaning. For him, theory of translation is neither theory nor science, but a gigantic group of knowledge. To fulfil the aims of the present study and verify its hypothesis, we adopt Newmark's Model (1988). Newmark's main contribution to the general theory of translation was the introduction of the next concepts: First, semantic translation which attempts to render, as closely as the semantic and syntactic structures of the TL allow, the exact contextual meaning of the original; semantic translation emphasizes the loyalty to the original text. It tends to reproduce the form of the original as close as TL norms will allow; additionally, no effort is made to change SL into a target culture context. Greater attention is paid to rendering the author's original thought-processing in TL, rather than attempting to interpret SL in a way which the translators consider most suitable for the target setting. Second, communicative translation attempts to create on its readers an influence as closely as possible to that obtained on the readers of the original. This means that in communicative translation the emphasis should be delete on transferring the message of the original in a form which conforms to linguistic, cultural and pragmatic conventions of TL rather than reflecting the real words of SL as close as possible without trespassing the TL norms.

Newmark (1981) feels that the success of equivalent effect is illusory and that the conflict of loyalties, the gap between emphasis on source and target language, will always remain as the essential problem in translation theory and practice (P.38). He proposes reducing the gap by substituting the old terms within those of semantic and communicative translation. Communicative translation attempts to render the exact contextual meaning of the original in such a way that both content and language are readily acceptable and comprehensible to the readership. While semantic translation, on the other hand, attempts to render as closely as the semantic and syntactic structures of the second language allow; the exact contextual meaning of the original. So, it is clear that communicative translation focuses on producing an equivalent effect on the target reader. On the contrary, semantic translation remains within the original culture at the author's linguistic level". This description of communicative 
translation resembles Nida's dynamic equivalence in the effect it is trying to create in the TT reader, while semantic translation has similarities to Nida's formal equivalence.

\subsection{Translation of Holy Quran}

Newmark (1988:5) proposes that translation is rendering the meaning of a text into another language in the way that the author intended the text. The word, author in the case of the Holy Quran makes a trouble and an obstruction for the translator to stop and think many times before choosing even one single word. In fact, he is dealing with a miracle which stands as is in any other language till the Judgement Day. Newmark states that understanding the text needs general and close reading. To grasp the intended meaning of the Holy Quran, the translator should read the verses in the original language many times. The general reading can be achieved through reading diverse exegesis of the Holy Quran, critical papers and illustrative analytical essays regarding specific topics that the text tackles. Such as society, culture, ethics, faith, heaven, hell, etc. The close reading, on the other hand, requires a wide research for the use of a text inside the original text. The translator's responsibility here is to look for places where figurative language is used, he or she should also find out the multiple functions and supplementary meanings one word might indicate to. In fact, there is no single word that comes by chance in the Glorious Quran (Al-Malik: 1995, P.17). Aziz and Lataiwish (2000:110), declared that although translations of the Quran may be helpful, yet they are unable to attain the genuine meaning of the Quran because both the message and the words expressing the message are divine. In translating such words into other words, this will make a loss in their divine value and therefore the message will lose its real meaning too. Al-Buti (2003) affirms that the translation of the Quranic verses presents a literal rendering which deform the implicit meanings of the verses.

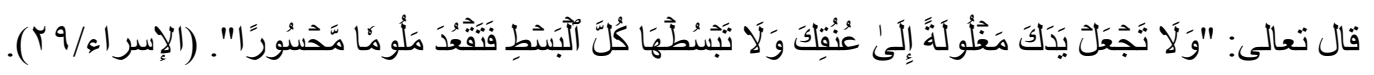

"And let not your hand be tied (like a miser) to your neck, nor stretch it for forth to its almost reach (like a spendthrift), so that you become blameworthy and in serving poverty (Al-Hilali and Khan:1977, P.372)". In this verse, the words do not indicate the real meaning, and as such, the translator should have a deep understanding of the Quranic and Islamic jurisprudence to translate them. Since the Quran is a unique book, it is better to transfer the meanings and the message of the Quranic verses rather than concentrating on the rendering of single words which may have no equivalent in the other language. Bell (1991:207) Delete space that to transfer the meaning and the force of the message of religious text from SL into TL, the translator should have an extensive information of all linguistic aspects in both languages.

\subsection{Reasons Behind Sarcasm in Holy Quran}

It has been made clear that there are many reasons behind using this technique which could be classified into two types due to the side from which sarcasm is issued. The first part, when the addresses are the polytheists, hypocrites or Muslim disobedient, the reasons are represented by:

First; the call to Allah Almighty as the book is guidance to all humanity: 


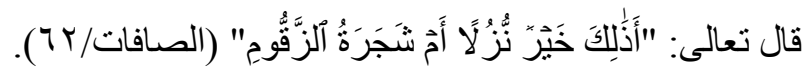

"Is that better as a hospitality, or the tree of Ez-Zakkoum (Arberry: 1955, 448)".

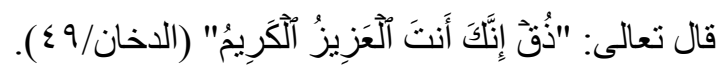

"Taste you this! Verily, you were (pretending to be) the mighty, the generous! (Al-Hilali and Khan: 1977, P. 674)". In these two verses and others, we can notice a very clear, inviting spirit; they launch a sever campaign of thread, menace and the warming of the consequences of the corrupt belief of those people being far away from the right path and method in a horrific and fearful way that makes them consider and think. This is a divine mercy, mocking them is an invitation for them to reverse their path which led them to be laughed at and a reason for death and destruction.

Second; defending the Prophets on top of them the Prophet Muhammad (PBUH) as a messenger who conveyed the Islam:

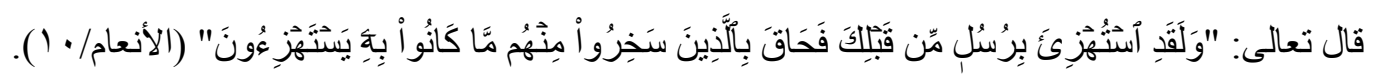

"And messengers before thee were indeed mocked, so there befell those of them who scoffed, that whereat they scoffed (Muhammad Ali:2002, P.654)". What the mockers said, expressed their feelings and opinions toward the Prophet as if Allah is saying that this is all they could get and what their ignorance led them to, because the Prophet has the upper hand over Quraysh masters and he came with a new superiority; the religion superiority which stripped them all means of competition though he had none (Hafni, A.:1992, P.420).

Third; defending the Muslims as guardians of the faith, and this falls in two ways:

Part one: the psychological campaign by Allah against his and the believer's enemies. The technique of mockery supports the believers to defend themselves as they are belied and made fun of. They do not have to react against mockery for there is who defends their case and stands by their side (The Holy Quran). An example of this like the following verses below:

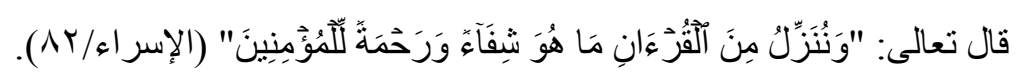

"And we send down, of the Koran, that which is a healing and a mercy to the believers (Arberry: 1955, P.290").

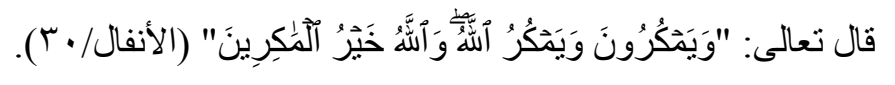

"They were plotting and Allah too was plotting; and Allah is the Best of those who plot (Al-Hilali and Khan: 1977, P.235)". Space, the reaction is always stronger and more severe as it is a book of challenge and miracles; another example is in the verse below:

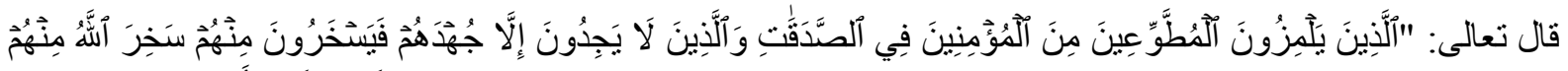

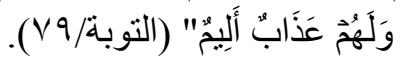

"Those who taunt the free givers of alms among the believers as well as those who cannot find anything (to give) but with their hard labor-they scoff of them. Allah will pay them back 
their mockery; and for them is a painful chastisement (Muhammad Ali: 2002, P.417)". Space is, he rewarded them for mocking the believers, so he mocked them.

Part two: this aspect implies that this technique effectively mobilizes Muslim's morally by providing them with one of the most brilliant artistic means in fighting the enemy and shattering their moral, and that is what we have obtained in the Holy Quran:

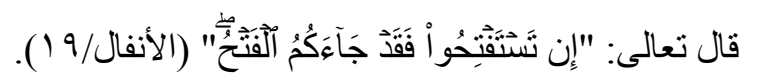

"If the victory you are seeking, the victory has already come upon you (Arberry: 1955, P.179)". Allah Almighty is addressing Quraysh's polytheists in Al-Badr battle. How great the influence of this speech is on them; as He called their defeat as Conquer! (Hafni, A.: 1992, P. 7).

Forth; the fourth reason is the various ways and techniques of speech. No doubt this indicates how eloquent and brilliant the speaker is and how capable he is to express the meaning required in various ways which makes the speech more attractive.

Fifth; the fifth reason is reforming and refinement. This is obvious in the Holy Quran as it sheds light on many ideological, legitimate and ethical violations or transgressions for both infidels and Muslims because the aim is reformation. Muslims need this more than the others as they are the example nation, and they should be of high morals compliance to Allah's orders. That is why the Holy Quran has mocked some breaches which may deform the religion and deprecate morals such as arrogance and hoarding money and the like.

Sixth; the sixth reason, persuasion and setting up the argument. Sometimes sarcasm is based on taking the opponent into account in order to lure him to persuasion and setting argument against him. This is made very clear in the dialogue of the Prophet Ibrahim with idols as if he was addressing mature human beings as in this verse saying:

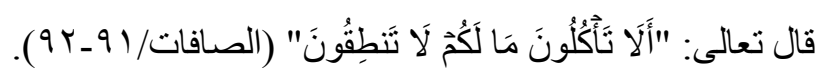

"Will you not eat (of the offering before you)? What is the matter you that you speak not? (Al-Hilali and Khan: 1977, P. 602)". Though the Prophet Ibrahim knew that they could not talk, but He wanted to silence his folk as they considered idols, their gods who capable of causing them harm or benefit.

The second part of the reasons is when sarcasm is made by the disbeliever's and hypocrites driven by:

First; disbelieving and obstinacy / الكفر و العناد:

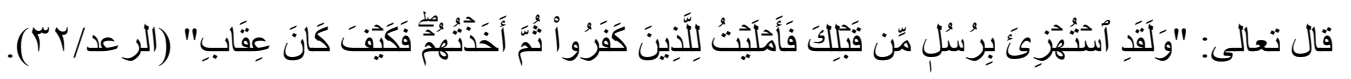

"And the messengers before thee were certainly mocked, but I gave respite to those who disbelieved, then I seized them. How (awful) was then My requital! (Muhammad Ali:2002, P.507)". That is, have you seen my punishment to those who made fun of my messengers! So, Allah called sarcasm disbelieving.

Second; hypocrisy / النفاق: Allah said, describing the manners of infidels: 


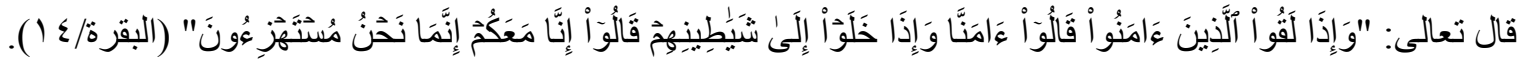

"And when they meet those who believe, they say: we believe, but when they are alone with their Shayatin (devils, polytheists, hypocrites), they say Truly, we are with you; verily, we were but mocking (Al-Hilali and Khan: 1977, P.5)". It was their hypocrisy which made them mock and laugh at the believers (Al-Baidhawi: 1996, P.114).

Third; ignorance and weak argument / الجكل و ضعف الحجة: which is clear in Musa's reply to his folk?

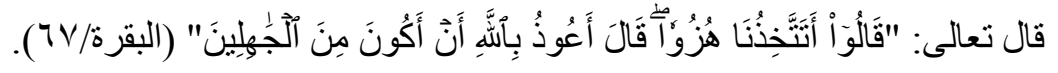

"They said: Dost thou ridicule us? He said: I seek refuge with Allah from being one of the ignorant (Maulana Muhammad Ali: 2002, P.35)". The word (الجاهلين) means mockers because taunt and irony during conveying the order of Allah is blindness and unawareness, and offense to the Prophets (Al-Baghawi: 1987, P.82).

\section{Method of the Study}

The study focusses on how sarcasm is translated in the Holy Quran in Arabic as the source language (SL) and English as the target language (TL). The study uses a qualitative research design to look at how sarcasm is translated in the Holy Quran. We chose the Holy Quran as the study's subject (the pragmatic uses of sarcasm are demonstrated with a number of verses chosen at random from Surahs of the Holy Quran, as well as three different English translations of the same text. (T1) Muhammad Ali (2002), (T2) Hilali \& Khan (1977), and (T3) Arberry are the three translations (1955). The translations are compared to the source text first, then to each other to see which one is better of rendering the same meaning and functionalities as the source text. Newmark's (1988) semantic and communicative translation model is used to examine and to evaluate how the intended meaning transferred sarcasm during the translation process from Arabic into English. Essence on areas of success and failure. When the translators are unable to offer an adequate translation, we recommend a rendition to convey the suggested sarcastic message and to express the intended ironic meaning.

\section{Results}

The main findings of the study are the translator has adopted two different approaches in their translations (Semantic and Communicative). In this case, unaware of the concept of sarcasm can give rise to inappropriate translations. Translators have produced distinct translations depending on their understanding of the verse's meanings. Ali (2002) and Arberry (1955) keep to the semantic method of translation in rendering the verses of the Quran most of times and used intemperance of synonymous for explaining the meaning of words without conveying the "force" of sarcastic expressions. Hilali and Khan's renderings (1977), on the other hand, displayed a communicative rendering in some cases, better than Ali and Arberry, still he could not reach the same effective meaning as it is in the Holy Quran.

In most cases, the renderings of the three translators sound unsuitable because they did not indicate the sarcastic function as it is in the (ST). Therefore, the three translators failed to 
express the intentional ironic meaning as it is in the SL (The Holy Quran), and also could not succeed to deliver the sarcastic message implied.

Table 1. Analysis of the translation of text (1)

\begin{tabular}{lll}
\hline \multirow{2}{*}{ Translators } & Adopted Translation & \\
\cline { 2 - 3 } & Semantic & Communicative \\
\hline Muhammad Ali & + & - \\
\hline Hilali \& Khan & - & + \\
\hline Arberry & + & - \\
\hline
\end{tabular}

This table shows that Ali and Arberry keep to semantic approach in rendering the meaning of the original text while Hilali \& Khan produced communicative translation.

Table 2. Analysis of the translation of text (2)

\begin{tabular}{lll}
\hline Translators & Adopted Translation & \\
\cline { 2 - 3 } & Semantic & Communicative \\
\hline Muhammad Ali & + & - \\
\hline Hilali \& Khan & + & - \\
\hline Arberry & + & - \\
\hline
\end{tabular}

This table shows that the three translations have produced a semantic method of translation in rendering the meaning of the verse of the original

Table 3. Analysis of the translation of text (3)

\begin{tabular}{lll}
\hline Translators & Adopted Translation \\
\cline { 2 - 3 } & Semantic & Communicative \\
\hline Muhammad Ali & + & - \\
\hline Hilali \& Khan & + & - \\
\hline Arberry & + & - \\
\hline
\end{tabular}

This table is similar to the previous one above showing that translators again retain to the semantic method of translation in rendering the meaning of the original

Table 4. The percentage of achieving semantic and communicative renditions of the selected verses

\begin{tabular}{lll}
\hline Translation Type & Frequency & Percentage \\
\hline Semantic & 8 & $\% 90$ \\
\hline Communicative & 1 & $\% 10$ \\
\hline Total & 9 & $\% 100$ \\
\hline
\end{tabular}

This table shows the percentage of achieving semantic and communicative renditions of the selected verses. Here, the frequency of semantic translation is higher than communicative. The translators keep to the semantic method in most of their translations to render the meaning of the verses of the original text. 


\section{Discussion}

After giving an appropriate description of sarcasm, exploring and investigating its meaning in Arabic. Now, the emphasis on the translation of sarcasm in the Holy Quran in Arabic as the source language and English as the target language. The Holy Quran is the text we chose to be the subject of the study (the pragmatic functions of sarcasm are explained with a number of verses that have been selected from random Surahs of the Holy Quran) in addition to three chosen English translations of the same text. The three translations are: (T1) Muhammad Ali (2002), (T2) Hilali \& Khan (1977) and (T3) Arberry (1955). The translations are compared first with the source text and then with each other to find out which one is the best to render the same meaning and functions as intended in the source text. The three translations are analyzed and assessed according to Newmark's Model (1988) semantic and communicative translation. We concentrate on areas of success and others of failure when translating sarcasm from Arabic into English. In some cases, when the translators are unable to produce a suitable translation, we propose a rendition to indicate the intentional ironic meaning and to transfer the sarcastic message implied.

ST (1):

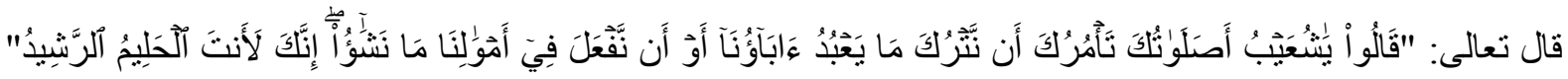
( $($ A $V / د)$

TT (1): "They said: O Shuaib, does thy Prayer enjoin thee, we should forsake what our fathers worshipped or that we should not do what we please with regard to our property? Forsooth thou art the forbearing, the right-directing one! (Muhammad Ali: 2002, P.470)".

TT (2): "They said: "O Shuaib! Does your salat (prayer) command that we give up what our fathers used to worship, or that we give up doing what we like with our property? Verily, you are the forbearer, right-minded!" (They said this)(Al-Hilali \& Khan: 1977, P. 298)".

TT (3): "They said: Shuaib, does thy Prayer command thee, that we should leave that our fathers served, or to do as we will with our goods? Thou art the clement one, the right-minded (Arberry: 1955, P.231)".

This verse includes two scenes of sarcasm by the folk of Shuaib showing disbelieving his teachings and the divine orders which are: The first scene attributes it all to prayer: Does your prayer order you to order us to abandon what our fathers' worship? These infidels of Shuaib people do not believe his divine teachings which forbid them from mistreatments and behaviors inherited from their fathers and ancestors, but they acted like ignorant who do not know if the prayer orders them to do so or not, as if they confessed that his prayer is correct, though in their hearts do not acknowledge any prayer, and they are quite positive there are nothing like orders or prohibitions related to it. They are just mocking as they deny the existence of Allah in the first place. Shuaib says: "Allah orders me", and as if they say there is nothing called Allah, and consequently there is nothing that orders you except your prayer which we see. The interrogation here is not real, it has been used for sarcasm and mockery (Mostapha, M.:1981, P.265). The second scene (إنك لأنت الحليم الرشيد) implies a sort of sarcasm by using words of praise in a mockery context; it is irrational to describe a call as 
hallucination, and it is only metaphorical indicating foolishness and rave for mockery and sarcasm purposes. They showed praise and respect and hid contempt and disregard (Hifni, A.:1992, P.25). In this verse, the people of Shu'ayb are ironically asking him if his prayer commands him that they should give up worshipping what their fathers used to do. It is as if they were ignorant and wanted to make sure! The truth is that they did not believe in his teachings nor his prophecy; they only aimed at ridiculing and mocking him. The three translators have used the same equivalent "prayer". Ali (2002, P.470) \& Arberry (1955, P.231) have put the word in a capital letter, while Al-Hilali and Khan (1977, P.298) have added the word "salat" to it. We suggest the following rendition: [Does your (religion of) prayer command thee, that we leave off the worship which our fathers practiced!]. So that it is more communicative compared with the three semantic renditions above. Unbelievers did not stop here; they continued their mockery by saying: [إنك لأنت الحليم الرشيد] [you are forbearing, right-minded]. Again, they did not mean it; they are only mocking the prophet. So, Al-Hilali \& Khan could express it properly by adding (they said this sarcastically). We could say that their rendition (Hilali \& Khan) is communicative compared to the other two renditions.

ST (2):

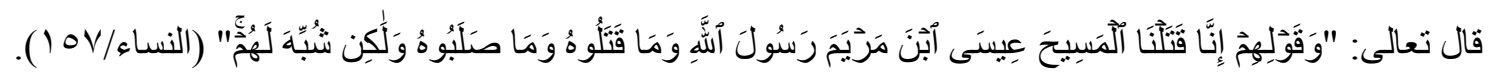

TT (1): "And for their saying: we have killed the Messiah, Jesus, Son of Mary, the messenger of Allah, and they killed him not, nor did they cause his death on the cross, but he was made to appear to them as such (Muhammad Ali:2002, P.237)".

TT (2): "And because of their saying (in boast), "we killed Messiah Isa (Jesus), son of Maryam (Mary), the messenger of Allah" _ but they killed him not, nor crucified him, but the resemblance of Isa (Jesus) was put over another man (and they killed that man) (Al-Hilali \& Khan:1977, P.136)".

TT (3): "And for their saying, we slew the Messiah, Jesus (Son of Mary), the messenger of God _ yet they did not slay him, neither crucified him, only a likeness of that was shown to them (Arberry: 1955, P.103)".

The evidence here is (رسول الله-Messenger of God). It has been either said by Allah to praise and honor Jesus, and to show how they dared to kill him, or it can be said by his folk ironically for it indicates that they do believe he is the messenger of God, but this contradicts with killing him. This speech is not real; they only aimed at underestimating him as they denied his prophecy. It

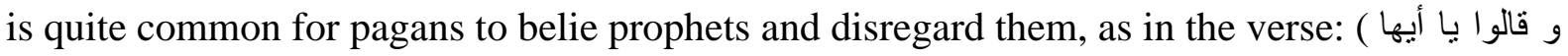

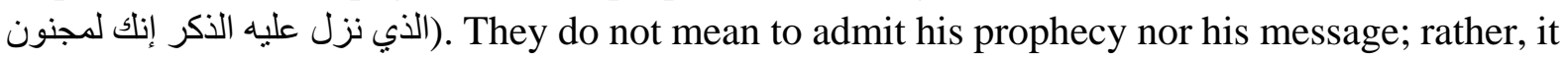
is ironic and neglection reasons. Confessing the message and revelation of Quran contradicts with madness (Abo Saud:1994, P.251). The evidence in this verse is: (Messenger of Allah-لرسول الهو); if this was said by the prophet's people (the unbelievers), it means they believe in his message. But they meant to make fun of him for it contradicts with killing him. The irony is quite clear here. The three translators have rendered it as: the Messenger of Allah, which is literally correct. However, in order to show the irony, they could have added an exclamation 
mark as a sign of the unbelievers' neglection and disregard to the prophet. Thus, their renditions are semantic.

ST (3):

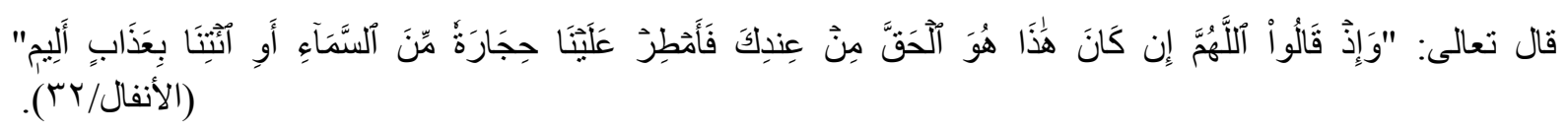

TT (1): "And when they said: O Allah, if this is indeed the truth from thee, then rain down on us stones from heaven or inflict on us a painful chastisement. (Muhammad Ali: 2002, P. 384)".

TT (2): "And (remember) when they said: “O Allah! If this (the Quran) is indeed the truth (revealed) from you, then rain down stones on us from the sky or bring on us a painful torment" (A-Hilali \& Khan:1977:P.235)".

TT (3): "And when they said, O God, if this be indeed the truth from Thee, then rain down upon us stones out of Heaven, or bring us a painful chastisement (Arberry: 1955, P.180)".

This verse denotes Quraysh's infidels belying and denying the prophet Muhammad's message and teachings; however, they are talking as if apologizing for a great misdeed they have committed, and asking Allah to purify them from this sin by punishing them with rocks from heaven the same as he did with the people of the elephant, or with any other punishment they deserve as if they confessed the existence of Allah, but their mistake was that they denied the revelation of Quran by Allah. Indeed, this is not the case; they neither believe in Allah's oneness nor revealing the Quran onto the Prophet Muhammad (PBUH) and his message to humanity all. They only spoke this way to confirm their ingratitude and denial by means of mocking the prophet and the believers (Al-Baidhawi:1996, P.105). In this verse, the infidels of Quraysh say: (فأمطر علينا حجارة من السماء أو آتنا بعذاب أليم)-(Rain down on us a shower of stones from the sky or send us a painful penalty). So, they do not believe in Prophet Muhammad's Message nor Al-Quran revealed unto him; they are not serious nor do they mean it. Their goal was sarcastic; they aimed at making fun of the Prophet and His message, stressing on their ingratitude and denial. The ironical image is clear in this Aya, but it is not in the three renditions as the three translators have given literal interpretations sticking to the wording of the Aya which made their renditions semantic. We suggest, in order showing the sarcastic image, adding an explanation between two brackets: (Mocking the Prophet or Challenging Allah).

\section{Conclusion}

The present study exposed that translating sarcasm in the Glorious Quran needs to convey its intended meaning and its exact sarcastic function as it is in the ST to maintain the influence created by sarcasm. In order to achieve this, the study tries to compare sarcasm in both languages (Arabic \& English) to find out how sarcasm is performed in the Holy Quran in both the source text (ST) and the translated text (TT. This is not an easy task because the Quran is a divine book related to Allah and it is hard to be submitted to modifications made by human interference. Therefore, misunderstanding of sarcastic expression that may cause 
mistranslating of sarcasm. As well as, footnotes are also needed in some cases to support the reader to understand the verses. To solve the different problems that translators face when translating the Holy Quran from Arabic into English, they try to use various techniques in order to create the same pragmatic effect as intended in the original text. Such variations affect the realization of the intended function. In cases where there was no word-to-word equivalence; they try to insert additional words to support in serving the purpose meaning in order to serve the same function. Concerning cultural-bound terms, they used explanation to make the conception clear for the target reader. It is believed that communicative translation of Newmark is the most suitable method for translating verses of the Holy Quran that imply sarcasm. But, in this study, the translators tend to use semantic method of translation (most of times) to render the meaning of the original text.

\section{References}

Abu Saud, M. (1994). IIrshad Al-Eaql Al-Salim IIlaa Mazaya Al-Kitab Al-Karim. Dar ihya Al-Turath Al-Arabi: Beirut.

Al-Alawi, Y. (1914). Al-Teraz Al-Mutathamin li asrar al-Balakh wa Ulum Haqaiq Al-ijaz. Cairo: Matbat Al-Moqtatif.

Al-Buti, M. S. (2003). Min Rawai? Al-Quran: Tamulat 'Ilmia wa Adabia fi Kitabu Allah 'Aza wa Jal. Beirut: Al-Resala Publishers.

Al-Farra, Y. A. Z. (1980). Maeani Al-Quran. Ealim Al-Kutub.

Al-Hilali, M. T. D., \& Khan, M. M. (1977). Translation of the meanings of the Noble Quran in the English Language. King Fahad Printing Complex.

Al-Hofy, A. (2001). Al-fukaha fi al-adab, usolha wa froaha. Cairo: Al-Hayia Al-Masria lil Kitab.

Ali, M. M. (2002). The holy Quran: Arabic text with English translation and contemporary. King Fahad. Holy Quran Printing Complex.

Al-Jurjani, A. (n.d.). Asrar al-balagha. Beirut: Dar Al-Kutub al-Ilmia.

Al-Madani, I. (1709). Anwar Al-Rabee fi anwa al-Badee. Beirut: Muassat Al-Marif.

Al-Malik, F. M. (1995). Performative utterances: their basic and secondary meanings with reference to five English translation of the meanings of the holy quran. Durham Theses, Durham University.

Al-Masri, Z. (1964). Tahriir Al-Tahriir fi sinãt Al-Shar wa Al-Nather wa-Bayan Ijaz Al-Quran. Cairo: Dar ihya Al-Turath Al-Arabi.

Al-Sakkãki, B. (1983). Miftâhu Al-Ulum. Beirut: Dar Al-Kutub al-Ilmia.

Al-Suleiman, K. (1991). Nathariat al-mufaraqa. Abhath Al-Yarmok, 9(2).

Al-Zamakhshari, A. Q. (1948). Al-kashâf an haqâiq al-tanzeel wa uyûn al-aqâwel fi wujûh al-taweel. Cairo: Maktabat Mustafa Al Halabi. 
Arberry, A. J. (1955). The Koran interpreted. The Macmillan Company, New York.

Aziz, Y., \& Lataiwish, M. (2000). Principles of translation. Bingazi: Dar al-Kutub Al-Watania.

Bell, R. T. (1991). Translation and translation theory and practice. London: Longman Group Ltd.

Cudden, J. A. (1979). A dictionary of literary terms. Chsthsn: Great Britain.

Haiman, J. (1998). Tlak is Cheapi Sarcasm, Alienation, and the Evolution of Language. New York: Oxford U.P., Inc.

Hifni, A. (1987). Islub Al-Sokhrya fi Al-Qurãn Al-Kareem. Cairo: Al-Haya Al-Masria lil kitab.

Ibn Al-Nadhim, B. (1989). Al-Misbah fi Al-Bayan wa Al-Maeani wa Al-Badie. Beirut: Dar Al-Kutub Al-Ilmia.

McDonald, S. (1999). Exploring the process of inference generation in sarcasm: a review of normal and clinical studies. Brain and Language, 88. https://doi.org/10.1006/brln.1999.2124

Newmark, P. (1981). Approaches to translation. Oxford; New York: Pergamon Press.

Newmark, P. (1988). A textbook of translation. London: Prentice Hall.

Toplak, M., \& Katz, A. (2000). On the Uses of Sarcastic Irony. Journal of Pragmatics, 32. https://doi.org/10.1016/S0378-2166(99)00101-0

Waliński, J. T. (2014). Translation procedures. Journal Article of University of Łódź, 29.

Wang, M. (2014). A study on semantic and communicative translation of magical things in Harry Potter. Studies in Literature and Language, 8(2), 26.

\section{Copyrights}

Copyright for this article is retained by the author(s), with first publication rights granted to the journal.

This is an open-access article distributed under the terms and conditions of the Creative Commons Attribution license (http://creativecommons.org/licenses/by/4.0/) 